\title{
A COMPARATIVE ANALYSIS OF THE PROPOSED MANDATORY NATURE OF EMPLOYMENT LEGISLATION AND ITS INTERACTION WITH THE CHOICE OF LAW OF AN INTERNATIONAL CONTRACT
}

by Marcia van der Merwe*

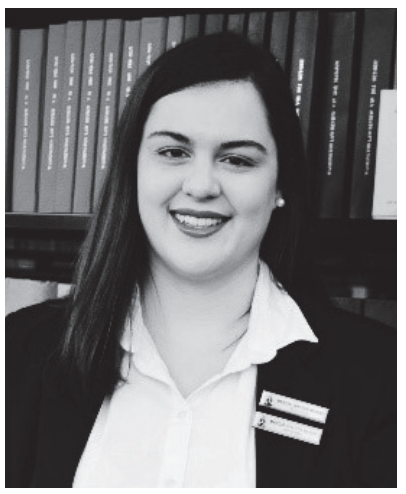

\section{Introduction}

In an ever-changing world characterised by globalisation there has been a steep increase in employment contracts with an international character. This may lead to a conflict of laws whereby a forum court is confronted with the application of either the forum's domestic laws or those of a foreign judicial system. In these cases we are confronted with the interaction between party autonomy and the limitations placed on the exercise thereof. The international legal community has yet to reach a consensus on the requirements of the exercise of party autonomy, and thus there are no 'supra-national laws' governing party autonomy. ${ }^{1}$

Only in extraordinary circumstances will the forum court divert from the proper law of the contract and in doing so veer from the

* BCom Law, LLB (cum laude), LLM Candidate in Private International Law (University of Pretoria). ORCID: 0000-0001-8838-5539. This article is based on the undergraduate dissertation submitted in partial fulfilment of the requirement for the degree LL.B. Many thanks and appreciation to Professor Elsabe Schoeman for her patience and encouragement.

1 PE Nygh 'The Limits on the Exercise of Autonomy' in PB Carter QC (eds) Autonomy in International Contracts (1999) 46. 
principle of freedom to contract. ${ }^{2}$ This is illustrated in Louks $v$ Standard Oil Company of New Jersey ${ }^{3}$ where Cardoza CJ stated so congruously in his obiter that 'we are not so provincial as to say that every solution of a problem is wrong because we deal with it otherwise at home ${ }^{4}$.' This article will endeavour to give an overview of the interaction between the proper law of a contract as chosen by the contracting parties in an international contract and the mandatory rules of a forum court that may be under consideration.

This article will undertake a critical comparison and analysis of the methods and reasoning applied by the courts in the jurisdictions of New Zealand, the United Kingdom and South Africa in respect of the mandatory nature of employment legislation and its interaction with the choice of law of an international employment contract. This will be done in reference to a specific company, Cathay Pacific, its employment contracts and the court cases that flowed from the choice of law clause in the contracts between Cathay Pacific and its employees in both New Zealand and the United Kingdom. A discussion of the possible repercussions of such a clause in a South African legal context will follow.

\section{A brief overview of the applicable private international law principles}

When a choice of law clause is subject to judicial scrutiny it may lead the court to highly technical questions and considerations. The international legal community does not subscribe to a universal set of rules pertaining to the exercise of party autonomy. ${ }^{5}$ Despite this, there are a set of international common law rules that municipal court's favour, which can be said to lead to an 'international consensus $^{\prime 6}$ of sorts on the matter. These requirements include, but are not restricted to: ${ }^{7}$

(1) that the contract has an international character;

(2) that the proper law of the contract has a connection with the transaction; parties or that there is a sensible reason for the choice;

(3) the proper law should be of an extant legal system and is bound by any changes thereof;

(4) the choice should not be illegal under the legal system of the forum, made with the intent to evade mandatory rules of the forum or another legal system or be irreconcilable with the public policy of the forum;

PE Nygh 'The Limits on the Exercise of Autonomy' in PB Carter QC (n 1 above) 46. Louks $v$ Standard Oil Company of New Jersey (1918) NY.

Louks (n 3 above) para 99.

PE Nygh 'The Limits on the Exercise of Autonomy' in PB Carter QC (n 1 above) 46. As above.

As above. 
(5) lastly, the choice must be made freely and voluntarily.

These requirements create a framework wherein the court considers a contract with an international character. It is not compulsory for all of these requirements to be met, nor are the requirements a numerus clauses. $^{8}$ The law of the lex fori, the law of the jurisdiction in which the action is brought, is applied to characterise the dispute and to determine the connecting factors. ${ }^{9}$

\subsection{The International character of the contract}

The question arises: what gives a contract an international character? Connecting factors that may arise in this characterisation include, but are not limited to, the place of business; nationalities or domiciles of the parties; if the place of contracting or performance is abroad; if remuneration is in a foreign currency or when property that is the subject of the contract is located abroad. ${ }^{10}$ Factors that are present at the time of contracting may change, and this change could subsequently lead to the contract taking on a more international or domestic form. The courts may also apply any of a number of tests to determine the internationality of a contract.

The economic test asks whether there is an economic impact on more than one jurisdiction, ${ }^{11}$ whereas the subjective test represents a more absolute view whereby the foreign choice of law in a contract makes an otherwise domestic contract, an international one. ${ }^{12}$ Another interesting test that will from part of the broader discussion of this article is the so called 'basing test' as laid down by Lord Denning in Todd $v$ British Midland Airways Ltd. ${ }^{13}$ This test is applied when determining the ordinary place of work of a peripatetic employee.

\subsection{Unlawfulness and public policy}

In Vita Food Products Inc. $v$ Unus Shipping Co, ${ }^{14}$ the Judicial Committee of the Privy Council greatly expanded on principle of party autonomy and matters of jurisdiction and proper law of the contract,

8 As above.

9 AV Dicey et al 'Characterisation' in L Collins (eds) Dicey and Morris on the Conflict of Laws Volume 1 (1993) 36.

10 PE Nygh 'The Limits on the Exercise of Autonomy' in PB Carter QC (eds) (n 1 above) 50.

11 PE Nygh 'The Limits on the Exercise of Autonomy' in PB Carter QC (eds) (n 1 above) 51

12 PE Nygh 'The Limits on the Exercise of Autonomy' in PB Carter QC (eds) (n 1 above) 52

13 Todd v British Midland Airways Ltd (1978) ICR 959 (CA) (thereafter 'Todd').

14 Vita Food Products Inc. v Unus Shipping Co.1939 AC 277 (thereafter 'Vita Foods'). 
especially with consideration to public policy and the legality of the choice.

The facts of Vita Foods are as follows. The defendant, a Nova Scotian corporation, was the owner of a ship (registered in Nova Scotia) that carried a cargo from Newfoundland to New York. The plaintiff, a New York corporation, was the owner of the cargo. The ship got stranded in Nova Scotia and the cargo was damaged. A waybill for the transportation of the cargo explicitly determined the contract to be governed by the English law. The contract also contained a term under English law that exempted the defendant from any liability for loss incurred as a result of negligence. The action was brought in Nova Scotia and went on appeal to the Privy Council. ${ }^{15}$ Lord Wright declared that a real connection with English law in this case was not essential but preferred to focus on public opinion; lawfulness and the proper law of the contract as the law that the parties intended to apply'. ${ }^{16}$ This case is considered to be a keystone in the modern development of the conflict of laws.

\subsection{Free and voluntary}

The requirement for a contract to be made freely and voluntarily underscores the need of the law to protect economically weaker parties, especially consumers; employees and the insured. ${ }^{17}$ This has become more relevant in the age of globalisation, where the need to protect individual employees is ever increasing.

\subsection{Connection with the proper law of the contract}

The proper law of a contract may refer to the law expressly chosen by the contracting parties in the so called 'choice of law clause' in a contract, or may be the law applicable to a contract as determined by a number of factors. ${ }^{18}$ In the past courts have considered the requirement of a factual connection between the contracting parties and the proper law non-essential. ${ }^{19}$ This is in direct contrast with the doctrine of localisation that requires some form of factual connection to apply the proper law of the contract.

Today it is commonplace for parties to choose a neutral legal system to govern a contract. The neutrality of the choice satisfies any

15 Vita Foods (n 14 above) 278-279.

16 Vita Foods (n 14 above) 290.

17 PE Nygh 'The Limits on the Exercise of Autonomy' in PB Carter QC (eds) (n 1 above) 69.

18 For the purpose of this article any reference to the 'proper law' of a contract will be in relation to the law applicable to a contract as expressly chosen by the parties in the choice of law clause of said contract. 
requirement for a 'rational basis' 20 for the choice of law of a contract. Thus, a connection between the proper law of a contract and the contract itself is not an absolute requirement but is a factor that a court may take into consideration. If parties are absolutely autonomous they will be at liberty to choose the legal system to govern the contract, regardless of connection, neutrality or the possibility of an injudicious choice. It is only where the proper law of the contract is in any way prohibited by a mandatory rule of the forum, is oppressive or unworkable that it will be set aside. ${ }^{21}$

\subsection{The Rome Convention and Rome Regulation}

Central to this discussion stands both the Convention on the Law Applicable to Contractual Obligations ${ }^{22}$ and the Regulation on the Law Applicable to Contractual Obligations, ${ }^{23}$ The United Kingdom ratified the Rome Convention with some reservation relating to the application of the legal rules it embodied. 24 This reservation was enforced domestically in the United Kingdom in section 2(2) of the Contracts (Applicable Law) Act ${ }^{25}$ which determined that article 7(1) of the Rome Convention had no force of law in the United Kingdom. Article $7(1)$ of the Rome Convention refers to the application or nonapplication of mandatory rules.

Rome I replaced the Rome Convention in its entirety. ${ }^{26}$ It is important to note that Rome I only finds application in matters heard within the jurisdiction of the European Union and applies to all the member states of the European Union, regardless of ratification (or lack thereof). ${ }^{27}$ This of course leaves us with the question: what will the way forward be relating to matters managed by EU instruments for the United Kingdom after its withdrawal from the European Union?.

\subsection{Mandatory rules}

Article 3.3 of Rome I defines mandatory rules as '... rules of law of that country which cannot be derogated from by agreement'. This is

20 PE Nygh 'The Limits on the Exercise of Autonomy' in PB Carter QC (eds) (n 1 above) 57.

21 PE Nygh 'The Limits on the Exercise of Autonomy' in PB Carter QC (eds) ( $\mathrm{n} 1$ above) 60.

22 Rome Convention on the Law Applicable to Contractual Obligations opened for signature in Rome on 19 June 1980 (80/934/EEC). (thereafter 'Rome Convention').

23 Regulation (EC) no 593/2008 of the European Parliament and of the Council of 17 June 2008 on the Law Applicable to Contractual Obligations (thereafter 'Rome I').

24 Rome I (n 22 above) art 27.

25 Contracts (Applicable Law) Act 1990.

26 Rome I (n 22 above) art 24.

27 This is often referred to as the direct effect or application of European Union law. 
indicative of the urgent nature of mandatory rules, which can override both the normal rules of the law of conflicts and the proper law as chosen by the parties. ${ }^{28}$ When considering mandatory rules one must distinguish between the domestic mandatory rules of a forum, international mandatory rules and mandatory rules of a third country that may be of relevance.

The domestic mandatory rules of a legal system can be viewed as an extension of the public policy of the legal system ${ }^{29}$ and may be used to enforce the application of mandatory rules within the jurisdiction of the forum court. In this sense mandatory rules may in certain instances place a limitation on the autonomy of the parties involved. 30

The forum is not obliged to apply domestic mandatory rules unless said laws are also part of the lex causae. ${ }^{31}$ It has been submitted that the forum is obligated to apply its own rules that are mandatory in the international sense at the expense of otherwise applicable law. ${ }^{32}$ There exists an assumption, which was supported by the wording of article 7(1) of the Rome Convention, that all mandatory rules of the lex causae are theoretically applicable, ${ }^{33}$ notwithstanding the domestic or international character thereof. In contrast a forum court is obliged to give paramount effect to international mandatory rules when adjudicating transnational matters, irrespective of the law of the cause. ${ }^{34}$

\subsection{Under what circumstances will the mandatory rules of a third state be applicable?}

An international consensus on the application of the mandatory rules of a third country has not yet been reached and as such it is up to the discretion of each forum to apply its own standards. ${ }^{35}$ There seems to be two circumstances in which the mandatory laws of a third state may be appropriate: ${ }^{36}$

a. where the law of the place of performance prohibits the performance as contractually stipulated; and Contracts (1999)199.

29 PE Nygh 'Mandatory Rules' in PB Carter QC (eds) (n 28 above) 206.

30 PE Nygh 'Mandatory Rules' in PB Carter QC (eds) (n 28 above) 207.

31 PE Nygh 'Mandatory Rules' in PB Carter QC (eds) (n 28 above) 212

32 As above.

33 PE Nygh 'Mandatory Rules' in PB Carter QC (n 28 above) 213; See also Report on the Convention on the law applicable to contractual obligations by Mario Giuliano, Professor, University of Milan, and Paul Lagarde, Professor, University of Paris I Official Journal C 282, 31/10/1980 0001 - 0050.

34 PE Nygh 'Mandatory Rules' in PB Carter QC (eds) (n 28 above) 199.

35 PE Nygh 'Mandatory Rules' in PB Carter QC (eds) (n 28 above) 225.

36 PE Nygh 'Mandatory Rules' in PB Carter QC (n 28 above) 226. 
b. where the forum views the unlawful conduct of the parties as immoral.

\subsection{Renvoi}

The doctrine of renvoi is often applied when choice of law rules favour foreign legal systems. It is described as a technique applied to problems arising from differences between connecting factors used by the law of country A and the law of country B to which the connecting factors (used by A) lead. ${ }^{37}$ Rome I explicitly excludes the application of renvoi and the doctrine is not applicable for the purposes of this discussion. 38

\section{Statutes and the conflict of laws}

When the application of the domestic statutes of a forum (or statutes foreign to the lex fori) are in question, it may in some cases necessitate the consideration of the mandatory nature of the statute itself. Dicey, Morris and Collins categorise statutory provisions, on the occasion of conflicting laws, into the following categories: ${ }^{39}$

a. statutes that impose a substantive or domestic law without indicating its application in space;

b. statutes that impose a unilateral rule of the conflict of laws that appears to indicate when a substantive or domestic law is applicable;

c. statutes that lay down a multilateral rule of the conflict of laws that appears to indicate when what law governs a matter;

d. statutes with a territorial limitation on the scope of their own application as domestic laws;

e. overriding statutes that apply in the circumstances provided for in the statute, even if they are not applicable under the normal provisions of the conflict of laws.

These overriding statutes are mandatory rules. Where a forum court deals with 'overriding' legislation it applies because the legislation is interpreted as mandatory, thus applying to all the cases within its scope. However, if a weaker party is afforded more protection in terms of the proper law of the contract (as determined by the choice of law clause) than the mandatory rules, the choice will be allowed. 40

Unfortunately, many courts' in different forums falter in the determination of the scope of these laws and rules. When confronted

37 P Rogerson 'Choice of Law Rules' in J Greenwood (eds) Collier's Conflict of Laws (2013) 280.

38 Rome I (n 22 above) art 20.

39 AV Dicey et al 'Statutes and Conflicts of Laws' in L Collins (eds) Dicey, Morris and Collins on the Conflict of Laws Volume 1(2012) 36.

40 This is in accordance with art 8 of Rome l. 
with the territorial application of legislation that does not indicate its own application in space, a court may follow one of two methods when determining the territoriality of the legislation. The first is to interpret the statute by way of its purpose and background, ${ }^{41}$ the second is to characterise the question on hand and then to apply the rules of conflict to the matter. ${ }^{42}$ The first method creates the possibility that a court may interpret the meaning of the Legislature incorrectly. It is submitted that, in most cases, where the Legislature considered the territorial application of a statute of importance, it would have been expressly be incorporated in said statute.

In following the second method suggested by Dicey, Morris and Collins a court would apply the rules of private international law; determine the scope of the relevant legislation and thereafter apply the provisions of the legislation, if applicable to the matter at hand. This method relies less on questionable legal interpretation and lends itself to an application that is in line with the laws of private international law as well as the broader consideration of public opinion. 43

As Norton and Fawcett so rightly state: '... applying the law of the forum, without more ... [is] an abandonment of the internationalisation of private international law. ${ }^{44}$ Thus in matters of the application of mandatory rules one must carefully strike a balance between private international common law and the domestic laws of the forum.

\section{The United Kingdom}

Before delving into the case law that forms the central part of this article, there is referred to the Todd case, where the court determined that the 'base' of a peripatetic employee is where he or she is ordinarily working, even though the employee may spend days, weeks or months working overseas. A matter of contention in such instances seems to be the meaning of 'ordinarily working'. For peripatetic employees ordinarily work where they are based. The conduct of the parties to the contract and the way in which they have been operating the contract are indicative to his or her 'base'. ${ }^{5}$ In Crofts $\vee$ Veta Ltd ${ }^{46}$, Lord Hoffman effectively described the plight of a peripatetic employee as that of the Flying Dutchman of labour law

41 This method is often described the presumption against extraterritoriality. See $M$ Keyes 'Statutes, Choice of Law, and the Role of Forum Choice' (2008) 4 Journal of Private International Law 18.

42 AV Dicey et al 'Statutes and Conflicts of Laws' in L Collins (n 39 above) 37 - 40.

43 This refers to public opinion as it is considered in the determination of the mandatory nature of a law or rule.

44 GC Cheshire et al 'Classification' in PM North (eds) Cheshire and North's Private International Law (1999) 6.

45 Todd (n 15 above) 5. 
'... condemned to fly without any jurisdiction in which they can seek redress...47

\subsection{The matter of Crofts}

In Crofts and Others $v$ Cathay Pacific Airways, ${ }^{48}$ the applicants were all pilots employed by Cathay Pacific; a company based in Hong Kong. For the sake of comparison, the focus will be on the court's handling of $\mathrm{Mr}$ Croft. The employment contract under scrutiny contains the same choice of law and jurisdiction clauses as the contracts considered by the New Zealand courts in the Brown-cases, though the matter before the court in this instance constitutes unfair dismissal in terms of section 49(1) of the Employment Rights Act. ${ }^{49}$

Cathay Pacific had a permanent basing policy where certain air crew were assigned a permanent base outside Hong Kong. Mr Crofts was based in London, where his individual flying cycles began and ended, under such policy. The employment contracts of the applicants determined the proper law of the contract to be that of Hong Kong. The pilot's salaries were paid into Hong Kong bank accounts; they had professional Hong Kong pilot's licences and received all their training there.

The application was dismissed the matter was taken to the Employment Tribunal based on unfair dismissal in terms of section 94(1) of ERA on grounds of failure to give written reasons for dismissal and breach of contract. Section 94(1) of ERA only applies to those who 'ordinarily work' in Great Britain. The Employment Tribunal found, after applying the basing-test, that they had jurisdiction over the matter. The appellant airline pilots appealed against the finding of jurisdiction and contractual claims. The Employment Appeal Tribunal dismissed the appeal. An appeal was brought before the Court of Appeal on the grounds that the Tribunal ought to have addressed whether the pilots had a proper connection with Great Britain and that in answering this question the focus must be the location of the pilots and not the locale of their employer. ${ }^{50}$

The court considered the judgment of Lawson $v$ Serco Ltd, ${ }^{51}$ in which the basing test was applied, but with a 'degree of flexibility'. 52 In his obiter Lord Phillips indicates that the degree of flexibility

Lawson v Serco Ltd; Botham v Ministry of Defence; Crofts and others $v$ Veta Ltd and Others [2006] 1 All ER 823 [2006] UKHL 3 (thereafter 'Crofts'). All three cases were heard together.

47 Crofts (n 46 above) para 31.

48 Crofts and Others v Cathay Pacific Airways (2005) EWCA Civ 599.

49 Employment Rights Act (thereafter 'ERA').

50 Crofts (n 48 above) para 15.

51 Lawson v Serco Ltd (2004) EWCA Civ 12.

52 Lawson (n 51 above) para 28. 
applied by the court in Lawson indicates that a temporary absence from Great Britain won't necessarily remove an employee from the protection of the ERA. ${ }^{53}$ This in itself is indicative of the mandatory nature of the ERA, but to my eternal disappointment, the mandatory nature of ERA was still not considered by the court.

Airline pilots are directly compared to mariners, which the court considers outside the scope of the Serco test. ${ }^{54}$ The opinion is held that Great Britain cannot be the pilot's place of work just because it is the place where their flight cycles begin and end. The place of work must be the place to which the employee has the closest connection or where he or she is based. ${ }^{55}$

Despite this, in Lawson the court expressly stated that the basing test laid down in Todd was not appropriate for the purposes of section 94(1). ${ }^{56}$ This created a problematic precedent that was followed by the court in Crofts. Lord Phillips expressed his discontent with this precedent therein that the basing test could not be applied to international airline pilots, and questioned whether this was against public policy. ${ }^{57}$ Here we see the court touching on the principles of mandatory provisions, but again without due consideration. The claim by the Cathay Pacific pilots, regarding the Tribunal's finding that it had no jurisdiction to entertain claims in terms of the ERA, was dismissed. ${ }^{58}$ Both the Crofts and Lawson cases were appealed to the House of Lords and heard together, and will be discussed hereafter.

In Crofts the House of Lords clearly stated the issue at hand was the territorial scope of section 94(1) of the ERA. ${ }^{59}$ The court explicitly found ERA to be prima facie territorial, ${ }^{60}$ and the only question regarding section 94(1) was one of construction where effect is given to the intent of Parliament regarding ERA and its application. ${ }^{61}$ With application of the Todd-basing test, the Employment Appeal Tribunal found Mr Crofts to be employed in Great Britain and the question of whether section 94(1) of the ERA would be applicable to be a question of law and not fact. 62

The court drew a distinction between 'expatriate employees' and 'peripatetic employees', and after applying the Todd basing test (and determining it to be applicable in this case, in contrast with the findings of the court in Lawson) Mr Croft, a peripatetic employee was found to be based in Great Britain and thus section 94(1) was

53 Crofts (n 48 above) para 28.

54 Crofts (n 48 above) para 35.

55 Crofts (n 48 above) para 36.

56 Lawson (n 51 above) para 27.

57 Crofts (n 48 above) para 37.

58 Lawson (n 51 above)) para 30.

59 Crofts (n 46 above) para 1.

60 Crofts (n 46 above) para 6

61 Crofts (n 46 above) para 23.

62 Crofts (n 46 above) para 34. 
applicable. The court held that section 94(1) was not applicable to expatriate employees. ${ }^{63}$

\subsection{Criticism on the handling of Crofts by the House of Lords}

In Crofts the House of Lords failed to reference section 204(1) of ERA which states:

For the purpose of this Act it is immaterial whether the law which (apart from this Act) governs any person's employment is the law of the United Kingdom, or of a part of the United Kingdom, or not. ${ }^{64}$

Section 204(2) states section 204(1) to be subject to section 196(1)(b), which determined that certain sections of ERA was not applicable to employees engaged in work 'wholly or mainly outside Great Britain', with certain exceptions. Section 196 was later repealed. Lord Hoffman interpreted the repealment as a sign that '... Parliament was dissatisfied with the working of the provisions and wanted to leave the matter to implication. ${ }^{65}$ It is uncertain how His Lordship came to these conclusions regarding Parliament's intentions surrounding ERA as he did not expand on the matter. The House of Lords seemed to have followed the first method of interpretation, as laid out by Dicey, Morris and Collins, whereby the purpose of statute was interpreted without first characterising the legal problem at hand. ${ }^{66}$

It appears from this judgment that the House of Lords is of the view that statutory employment rights, such as those embodied in ERA, do not have a sui generis character that make them mandatory in nature. This matter appeared before the House of Lords in 2006, before the commencement of Rome I. Although the United Kingdom has ratified Rome I's predecessor, the Rome Convention, with certain reservations. ${ }^{67}$ It is problematic that the court gave no consideration to choice of law rules, the possibility of the mandatory nature of ERA or to the considerations of public opinion. Here article 8(1) of Rome I, regarding individual employment contracts, is of particular importance:

An individual employment contract shall be governed by the law chosen by the parties in accordance with Article 3 (referring to the freedom to

63 Crofts (n 46 above) paras 31-46. The court held that a peripatetic employee's work was considered to be performed in Great Britain if the employee was based there at the time of dismissal (as found to be in Mr Crofts case). In the case of an expatriate employee the court held 'something more' must be present for the section to find application, and Lord Hoffman went on to give to very specific constructions of this 'something more', thus limiting its application.

64 See (n 48 above).

65 Crofts (n 46 above) para 9.

66 AV Dicey et al 'Statutes and Conflicts of Laws' in L Collins (n 39 above) 37 - 40.

67 The Rome Convention was ratified by the United Kingdom with reservations regarding arts $7(1)$ and $10(1)(\mathrm{e})$. 
choose the law governing a contract). Such a choice of law may not, however, have the result of depriving the employee of the protection afforded to him by provisions that cannot be derogated from by agreement under the law that, in the absence of choice, would have been applicable pursuant to paragraphs 2, 3 and 4 of this Article. ${ }^{68}$

Article 9(2) explicitly allows courts to apply overriding domestic mandatory rules of the forum. Article 9(1) defines overriding domestic mandatory provisions as:

regarded as crucial by a country for safeguarding its public interests, such as its political, social or economic organisation, to such an extent that they are applicable to any situation falling within their scope, irrespective of the law otherwise applicable to the contract under this Regulation. ${ }^{69}$

Rome I mirrors almost precisely the content of article 6 of the Rome Convention, which dealt with individual employment contracts and explicitly stated that a court must look at the place where an employee 'habitually' carries out his work in the absence of a choice of law in the contract itself. Though this was only where there was a lack of choice, the habitual place of work is a sensible connecting factor to consider. ${ }^{70}$

What makes the non-consideration even more lamentable is that the United Kingdom held no reservations regarding article 6 of the Rome Convention and that the Rome Convention was incorporated into Schedule One of the Contracts (Applicable Law) Act, ${ }^{71}$ which was enacted long before this matter was heard.

With this is mind, it seems from this judgment that either the House of Lords did not consider employment rights, specifically the right not to be unfairly dismissed, in a mandatory light or that they did not attach much consideration to EU Regulations that is in effect an embodiment of private international common law. ${ }^{72}$

Contrary to the content of the Rome Convention (and the later Rome I) and the Contracts (Applicable Law) Act the House of Lords followed a traditional common law approach, wherein an employee may only invoke his statutory right if he falls within the territorial scope of the statute. Following this construction the territorial scope of any statutory employment rights is completely separate from the choice of law. Again, the House of Lords solely relied on the statutory construction when considering whether an employee may invoke a statutory right. ${ }^{73}$

68 Rome I (n 22 above).

69 Rome I (n 22 above).

70 TC Hartley 'Choice of law' in J Bomhoff (eds) International Commercial Litigation (2015) 559560.

71 See (n 24 above).

72 Common law as it finds application within the European Union.

73 Crofts (n 46 above) para 34. 
It is submitted that the House erred in their determination of the intention of the Legislature in regards to the scope and territorial application of ERA. This method leaves too much room for error and courts would do well to first characterise the question and then apply the rules of conflict to the matter.

Furthermore, ERA, and national labour legislation of a forum court in general, is of great importance and is of a mandatory nature and falls within the ambit of a mandatory provision as described in article 9(1) above. Therefore, it is contended that the legal construction followed by the House of Lords in this case is wrong, and that it was not merely a question of statutory construction, but that the question should have been answered with due consideration of the choice of law rules. ${ }^{74}$

In a more recent judgment the Supreme Court in Duncombe and Others $v$ Secretary of State for Children, Schools and Families (No $2)^{75}$ veered slightly from the traditional construction followed in Crofts and held the proper law governing the employment contract was relevant in determining the territoriality of a statutory right. ${ }^{76}$ The court in Duncombe held that the statutory protection against unfair dismissal, though not part of contractual terms and conditions of employment, was formulated by Parliament to protect employees where common law was lacking. ${ }^{77}$ Why the House of Lords did not consider this approach in Crofts can possibly be attributed to the fact that Duncombe was heard in 2011, after the enactment of Rome I. It may also be that the court in Duncombe merely followed the correct method and application of private international law rules. This illustrates the danger that inferring the intent of the Legislature can hold - the same court attached different interpretations to very similar matters.

The nature of the right, contractual or statutory, did not feature in the reasoning of the court. From the judgment it can be deduced that the court dealt with the right as a statutory one, and not as contractual in nature. If it is argued that a right conferred by employment legislation is contractual, it might be construed that Parliament intended the right to be invoked whenever the law governing said contract is English. ${ }^{78}$

74 This concurs with the position taken by the author in U Grušic 'The Territorial Scope of Employment Legislation and Choice of Law' (2012) 75 Modern Law Review 722. This is regardless of the fact that the United Kingdom ratified the Rome Convention with reservations on the applications of art 7(1).

75 Duncombe and Others $v$ Secretary of State for Children, Schools and Families (No 2) (2011) UKSC 36 (thereafter Duncombe).

76 Duncombe (n 75 above) para 16.

77 Duncombe (n 75 above) para 16.

78 Grušic (n 74 above) 733. 


\subsection{Where does this approach stem from?}

This traditional approach of the House of Lords seems to cling to and possibly be attributed to the formalistic nature of English courts and the English legal system. The historic background given by the author Uglješa Grušić, ${ }^{79}$ paints a picture of a legal culture ruled by a stubborn adherence to long passed 'judge-made' choice of law rules with no consideration (and some measure of contempt) to the legislation adopted by the European Union in Brussels. ${ }^{80}$

\subsection{Forum non conveniens}

Forum non conveniens is a legal doctrine of the conflict of laws whereby an English court has an inherent jurisdiction to stay proceedings on the ground that another forum is more appropriate to hear the matter or to strike out an action to prevent injustice. ${ }^{81}$ The doctrine may apply between forums in different countries or different jurisdictions in the same country. The defendant will carry the burden of proof in such cases and will have to prove that there is a more convenient or fitting forum where the matter can be heard. ${ }^{82}$

Although the Employment Tribunal in Crofts held that it had a general power to stay proceedings based on forum non conveniens, the House of Lords held (on the same matter) that it would go against principle for a section 94(1) application under ERA to be stayed on these grounds. ${ }^{83}$ It is not evident to what 'principle' the court is referring to, but it is submitted that this is further indicative of the mandatory nature of the rights at hand, and that the House of Lords again touched on the sui generis character of employment rights, but without due consideration thereto.

\section{$5 \quad$ New Zealand}

\subsection{The matter of Brown}

In Brown v New Zealand Basing Limited ${ }^{84}$ senior Captains' Brown and Sycamore were both employed by Veta Ltd, a subsidiary of Cathay Pacific Airways Ltd, until 2002. Thereafter they were offered new Conditions of Service under New Zealand Basing Limited (thereafter

81 AV Dicey et al 'Forum Non Conveniens and Lis Alibi Pendens' in L Collins (eds) Dicey and Morris on the Conflict of Laws Volume 1 (1993) 397.

82 AV Dicey et al 'Forum Non Conveniens and Lis Alibi Pendens' in L Collins (n 81 above) 397.

83 Crofts (n 46 above) para 24.

84 Brown v New Zealand Basing Limited (2014) EMPC 229. 
'NZBL') a subsidiary of Cathay Pacific. They were given the choice to remain in Auckland with a salary deduction working for NZBL or they could return to Hong Kong without a reduction to their respective salaries. Both Mr Brown and Sycamore chose to accept the 2002 Conditions of Service with a permanent basing in Auckland for NZBL. In 2008 NZBL offered the crew of NZBL new Conditions of Service. These conditions stipulated that pilots who were employed before 1 April 1993 would be able to work until the age of 65 , but with a substantial cut to their remuneration. Those who decided to stay on in terms of the 2002 Conditions of Service would receive the same salary they always had, but they would only be able to work until the age of 55. This is in direct contravention of Part 9 of the Employment Relations $\mathrm{Act}^{85}$ which includes, amongst others, the right not to be discriminated against on the basis of age. ${ }^{86}$

Both the 2002 and 2008 Conditions of Service contained a choice of law clause that explicitly stated that the applicable law was that of Hong Kong and that the parties would submit to the exclusive jurisdiction of the courts of Hong Kong. The Employment Court discarded the proper law of the contract and found that section 238 of ERA 2, which determined that parties could not contract out of any of the provisions in said Act, to be applicable. ${ }^{87}$ It was held that the law of the forum court, that of New Zealand, overrode the choice of law clause as the lex causae of the contract. ${ }^{88}$ The Employment Court held ERA 2 to be an example of a mandatory law or rule. Alternatively, the court found that the choice of law clause would not have been applicable had they found ERA 2 not to have a mandatory nature, seeing as it would have also been contrary to public policy, as the recognition of Hong Kong law under the circumstances would have been 'unjust and unconscionable' in the eyes of the New Zealand public. Furthermore, the court found the 'bona fide and legal'-test was not infringed upon. ${ }^{89}$

In New Zealand Basing Limited $v$ Brown ${ }^{90}$ NZBL took the abovementioned matter in Brown $v$ New Zealand Basing Limited on appeal. The Court of Appeal extensively discussed the basic principles of choice of law and found Corkill $J$ to have transgressed by way of two material errors, namely that he did not follow the correct methodology when applying the law regarding the conflict of laws and

85 The Employment Relations Act 2000 (thereafter' ERA 2'), not to be confused with the Employment Rights Act of 1996, referred to as ERA.

86 ERA 2 (n 85 above) subsecs 105(2) and 106. New Zealand has no retirement age, and employees may in theory work until they decide to retire.

87 Thus, with the application of sec 238, they could not contract out of the antidiscrimination provisions of ERA 2.

88 Brown (n 84 above) paras 130 - 134

89 As above.

90 New Zealand Basing Limited v Brown (2016) NZCA 525 (thereafter 'New Zealand Basing Limited'). 
that he had misunderstood Parliament's intent towards ERA 2 (as a mandatory law). The methodology set out by the court determines a court considering such a matter must proceed from the assumption that the proper law of the contract is applicable, and will consequently govern the rights and obligations of the parties of the contract. A court may only look toward the possibility of any applicable mandatory laws when there has been determined that the lex causae is that of a foreign legal system. The Supreme Court was of the opinion that the intent of the New Zealand Parliament was not that ERA 2 was to have overriding power against the rules of private international law. ${ }^{91}$

The methodology set out by the Appeal Court is of great importance. It lays the groundwork for the correct application of the principles of the conflict of laws. Some argue that the forum court must look at the character of the rules or laws in question before determining the lex causae, seeing that a mandatory provision will make the consideration pertaining to the lex causae moot. The Court of Appeal followed the approach whereby the right invoked in terms of section 9 of ERA 2 was a contractual right, and following the principles of choice of law, was only applicable where New Zealand law governed the contract or where the legislative provisions from which the right stemmed was mandatory. ${ }^{92}$

On the matter of whether the public policy exception would have been acceptable the court emphasised the extraordinarily high threshold required for the exclusion of the proper law of a contract based on public policy. The court was of the opinion that this particular case of age discrimination did not meet this threshold, and consequently the public policy exception was not justified. ${ }^{93}$ The appeal was allowed. In contrast to the position taken by the House of Lords in Crofts is Brown v New Zealand Basing Limited. ${ }^{94}$

The Supreme Court found the right against discrimination based on age not to be limited to employment agreements where the lex causae of the contract is that of New Zealand law. The court confirmed the mandatory essence of ERA 2 and the judgment of the Employment Court was restored. It was held that an employer's right not to be discriminated against, while in this case having a contractual 'flavour', cannot be characterised as such. ${ }^{95}$ The court found non-discrimination rights within in the Human Rights Act, ${ }^{96}$ as they are contained in ERA 2, to be '... free standing ... not dependent on ... or related to the terms of the employment agreement between

91 New Zealand Basing Limited (n 90 above) paras 30 - 33.

92 New Zealand Basing Limited (n 90 above) para 33.

93 As above.

94 Brown v New Zealand Basing Limited (2017) NZSC 139 (thereafter 'Brown').

95 Brown (n 94 above) para 53.

96 Human Rights Act 1993 No 82. 
parties. ${ }^{, 97}$ Thus the right to not be discriminated against was held not to be limited to employment relationships governed by the laws of New Zealand. ${ }^{98}$

There is no equivalent to section 204 of ERA (the Employment Rights Act of the UK) in ERA 2, and as the court points out, the legislation (ERA 2) itself gives no indication of its own territoriality. ${ }^{99}$ The Supreme Court relied on other criteria to determine the territorial application of ERA 2. Here the Court characterised the issue, identified the choice of law rule applicable and then considered the nature of the statute. This approach gives priority to the choice of law rule for employment contracts when determining the territorial scope of the employment legislation. ${ }^{100}$

\subsection{Forum non conveniens}

It is interesting that the jurisdiction of the New Zealand courts were challenged based on the choice of law being that of Hong Kong, and that the respondent failed to argue that matter with reference to the doctrine of forum non conveniens.

\subsection{On the nature of the Employee Relations Act}

The cases discussed above deal with an employee's right not to be discriminated against, which is in essence different from the Crofts case where the courts dealt with the right against unfair dismissal. Human Rights in New Zealand are entrenched within an Act, the Human Rights Act, ${ }^{101}$ whereto ERA 2 refers with relation to its antidiscrimination provisions. Despite the fact that these two cases deal with rights that are materially different, ${ }^{102}$ one does not lessen the mandatory character of the other. Therefore the rights embodied in ERA 2 can be considered to be of an overriding nature, as they represent 'crystallised rules of public policy' ${ }^{, 103}$ that gives effect to a forum's substantive interests. ${ }^{104}$

97 New Zealand Basing Limited (n 90 above) para 69.

98 Brown (n 94 above) para 71.

99 Brown (n 94 above) para 66.

100 Grušic (n 74 above) 723.

101 See (n 96) above.

102 Materially in the sense that one is an internationally acknowledged human right and the other is a right born from employment statute.

103 AV Dicey et al 'Statutes and Conflicts of Laws' in L Collins (n 39 above) 61.

104 M Hook \& J Wass 'The Employment Relations Act and its Effect on Contracts Governed by Foreign Law' (2017) 3 New Zealand Law Journal 80. 


\subsection{The influence of Rome I}

Despite New Zealand not being a member state of the European Union, and thus Rome I does not find any direct application, the judgments discussed above indicate that the courts involved gave due consideration to principles of private international common law. ${ }^{105}$ The New Zealand courts (the Employment Court, the Appeal Court and the Supreme Court) all demonstrated a very thorough, concise and structured approach to the conflict between the proper law of a contract and possible mandatory rules of the forum.

\section{South Africa}

Cathay Pacific Airlines have subsidiaries in South Africa, but unfortunately for the purposes of this article, their labour practices in South Africa have yet to result in adjudication similar to those in Crofts and Brown. ${ }^{106}$ Therefore, for purposes of this discussion, comparative scenarios that have been brought before the Labour Court, and how they have been adjudicated under South African law will be discussed.

\subsection{Related case law}

In Kleynhans $v$ Parmelat ${ }^{107}$ the applicant, a South African employee, was sent to work in Mozambique on a three-year fixed-term contract. The contract was terminated after one year and the employee claimed for breach of contract. Parmelat South Africa claimed not to be the employer as he had worked in Mozambique and not South Africa. The court held that the parties tacitly chose South African law as the law governing the contract, and in the event that this was wrong, they also determined the proper law was South Africa with reference to the connecting factors of the case. ${ }^{108}$

What distinguishes Kleynhans from preceding South African judgments on similar issues, is that for the first time a South African court did not treat the place of performance as the most important connecting factor when determining the lex causae, but only as one of many relevant factors. Pillay J further substantiated South African law as the lex causae: "If the law of the forum subscribes to international labour and human rights standards it is ... a factor that favours the law of such forum.' 109 Though Kleynhans did not deal with

105 Many of these principles were captured in Rome I.

106 See (n 48 above) and (n 94 above).

107 Kleynhans $v$ Parmelat (2002) 9 BLLR 879 (LC) (thereafter 'Kleynhans').

108 Kleynhans (n 107 above) paras 28 - 29.

109 Kleynhans (n 107 above) para 82. 
mandatory rules (overriding statutes) it is a principle judgment on the determination of the proper law of an international contract in South African courts.

In Parry $v$ Astral Operations $L t d^{110}$ a South African company was responsible for the operations of the respondent in Malawi. The applicant was retrenched and claimed damages for breach of contract in terms of the Basic Conditions of Employment Act, ${ }^{111}$ unfair dismissal in terms of the Labour Relations Act ${ }^{112}$ and in the alternative a claim for infringement of his constitutional right to fair labour practices in terms of section 23(1) of the Constitution. ${ }^{113}$ In the absence of a choice of law clause the court held that there was an implied choice of South African law as the proper law of the contract and even if this was incorrect the contract had a more substantial or real connection with South African law. ${ }^{114}$

In the case of a contract not having a choice of law clause the South African courts refer back to the legal system with the "closest and most real connection.' 115 Van Rooyen refers to this as the '... enigste verbonde regstelsel'. ${ }^{116}$ In most cases the legal system with the closest and most real connection is the one 'the Courts would presume to have been intended by the parties.' 117

The court denoted South African labour legislation to be of a mandatory nature and that it was directly applicable to all employment contracts in South Africa. ${ }^{118}$ The court found that 'any law' (with the exception of the Constitution or an amending statute thereto) conflicting with the Employment Equity Act ${ }^{119}$ or LRA to be subordinate. ${ }^{120}$ 'Any law' may also refer to foreign law. ${ }^{121}$

In the case of the contract having a choice of law clause, the Labour Court was prepared to be guided by section 6 of the Rome Convention on the Law Applicable to Contractual Obligations. ${ }^{122}$ The court would only uphold the proper law of the contract if it did not

110 Parry v Astral Operations Ltd 2005 (10) BLLR 989 (LC) (thereafter 'Parry').

111 Basic Conditions of Employment Act 75 of 1997 (thereafter 'BCEA').

112 Labour Relations Act 66 of 1995 (thereafter 'LRA').

113 The Constitution of the Republic of South Africa, 1996 (thereafter the 'Constitution').

114 The latter was determined by way of connecting factors, such as the place of conclusion of the contract was South Africa and the employee was under the direct supervision of the South African employer.

115 As applied by Grosskopf J in Improvair (Cape) (Pty) Ltd v Establisssements Neu 1983 (2) SA 138152.

116 JCW van Rooyen, (1972) 'Die Kontrak in die Suid-Afrikaanse Internasionale Privaatreg', LLD Thesis, University of Pretoria, p. 218.

117 Improvair (n 115 above) 147.

118 Parry (n 110 above) para 62.

119 Employment Equity Act 55 of 1998 (thereafter 'EEA').

120 Parry (n 110 above) para 56.

121 Parry (n 110 above) para 56.

122 Parry (n 110 above) para 71. 
deprive the employee of the protection afforded by the mandatory rules of the forum court (South Africa). ${ }^{123}$

The methodology suggested by the court is to first establish whether an employee has been deprived of the protection of a mandatory rule. ${ }^{124}$

\subsection{Labour rights in South Africa}

It is submitted that in South Africa, labour rights enjoy an elevated status as constitutional rights. In the Parry case the court considered, amongst others, a claim for unfair dismissal. ${ }^{125}$ In South Africa the right to fair labour practices (and consequently the right against unfair dismissal) is constitutionally entrenched in section 23(1) of the Constitution. ${ }^{126}$ As Pillay $J$ stated so eloquently: '... the constitutionalism of labour rights strengthens the public policy and protective components of labour law. 127 The EEA, LRA and BCEA can be viewed as 'crystallised public policy'. ${ }^{128}$

\subsection{Access to justice as a domestic mandatory rule}

In Kleynhans the Labour Court held that an 'added reason,129 for assuming jurisdiction in this matter would be that if the court did not do so, the applicant would be left without a forum to pursue his claim. ${ }^{130}$ Here the court adds a never before considered reason for assuming jurisdiction, ${ }^{131}$ namely the constitutional right of access to courts. ${ }^{132}$ In Parry the Labour Court again held that a contributing factor for assuming jurisdiction over the matter would be the fact that a Malawian court may refuse jurisdiction, ${ }^{133}$ which infers that it again would be in contravention of the applicants right to access to courts, and thus his right to access to justice, if the Labour Court were to refuse jurisdiction.

From these two cases it would appear the Labour Court treats the right to access to courts, as it is entrenched in the Bill of Rights, as mandatory in nature. It is thus submitted that the right to access to courts, and consequently all rights contained in the Bill of Rights, are

123 Parry (n 110 above) para 72.

124 As above.

125 Parry (n 110 above) para 1.

126 See (n 113 above).

127 Parry (n 110 above) para 53.

$128 \mathrm{~K}$ Calitz 'Globalisation, the Development of Constitutionalism and the Individual Employee' (2007) 10 Potchefstroom Electronic Law Journal 2/115 9/115.

129 Calitz (n 128 above) $10 / 115$.

130 Kleynhans (n 107 above) para 47.

131 Calitz (n 128 above) p 11/115.

132 The Constitution (n 133 above) sec 34.

133 Parry (n 110 above) para 78. 
domestic mandatory rules that are to be considered by all courts within South Africa. ${ }^{134}$

The right to access to courts may in future be applied to establish jurisdiction in the same way that the principle of forum non conveniens is applied to stay proceedings. This could lead to an influx of litigation in South African courts like what has in recent years been seen in the United Kingdom and may be misused as a foothold for forum shopping. Despite recent judgements and legal development seen in the Labour Court, private international law in South Africa is still its infancy and there is a need for development domestically regarding this area of the law.

\subsection{The approach of the South African Labour Court}

In Parry the Labour Court, much like the Supreme Court in Brown, relied on the principles of the Rome Convention, even though South Africa was neither a signatory thereof nor are we a member state of the European Union. The Labour Court substantiated this reliance with the fact that no part of the Rome Convention conflicts with either the Constitution or domestic labour laws. ${ }^{135}$ The case of Parry was heard before the commencement of Rome I (which replaced the Rome Convention in its entirety), but this does not mean that Rome I cannot be used as a guiding force in these matters.

In the obiter of Parry the court comments on the scarcity of academic material pertaining to labour law within the field of conflict of laws in South Africa. ${ }^{136}$ This may be an area of the law that is underdeveloped and where there is a lack of relevant case law, like the instance of peripatetic employees such as in Brown and Crofts. In matters pertaining to the conflict of laws South African courts would do well to look to Rome I for guidance. The content of the Convention is not in conflict with any provisions of South African Labour Legislation or the Constitution itself.

It can be said that South African courts 'develop the rules of private international law,137 in accordance with section 39(2) of the Constitution when they stress the mandatory nature of labour rights and their entrenchment in the Constitution by relying on the Rome Convention.

This comparative approach taken by the court is also in accordance with section 233 of the Constitution, wherein a court may

134 See (n 113 above) chapter 2.

135 Parry (n 110 above) para 71.

136 Parry (n 110 above) para 30.

137 Calitz (n 128 above) p9/115. 
'... refer any reasonable interpretation of the legislation that is consistent with international law ...,138

The Constitution has not been the catalyst for fundamental change to private international law as it is applied in South Africa, but the possibility does exist. The private international law rules applied by domestic courts has (thus far) been consistent with the Constitution, thusly 'the new constitutional order does not dominate but exerts a beneficial influence of this branch of law. ${ }^{139}$ The methods applied by the Labour Courts in the cases above can be distinguished from that of the United Kingdom and New Zealand. This may be attributed to the era of transformative constitutionalism South Africa is currently experiencing and the courts commitment to constitutional rights and substantive adjudication.

\section{Conclusion}

In an ideal world all jurisdictions would submit to a uniform approach and set of rules that govern the conflict of laws in private international law. From the discussion above it seems that the courts of South Africa and New Zealand are, in the absence of clear guiding principles of their own, willing to look to instruments of the European Union in this regard. This is indicative of both the need of countries outside the European Union for academic writing on this matter and to develop regulatory framework that can be applied uniformly to such instances.

In a world characterised by globalisation there is an increase in the need to balance the interests of the individual employee and those of the conglomerates they work for. This gives rise to a duty of the courts from all jurisdictions to protect employees involved in international employment contracts. This, unfortunately, remains a challenge for all parties involved.

138 See (n 113 above) sec 233.

139 C Forsyth 'Introduction' in C Jesseman (eds) Private International Law: The Modern Roman-Dutch Law Including the Jurisdiction of the High Courts (2003) 11. 